\title{
Linguistic Analysis of English Advertising Slogans in Yachting
}

\author{
Tomislav Skračić, Petar Kosović
}

The paper discusses the linguistic characteristics of yachting slogans, short messages that advertise sail and power boats, boating equipment and services in nautical magazines. The objective of the paper has been to identify and describe the language features of yachting slogans at phonological, lexical, syntactic and semantic level, with due attention drawn to the functionality of these messages in comparison with the messages relayed by slogans in other trades. The study has revealed that, due to the specific market niche, most yachting slogans tend to use specific language devices and discourse. The qualitative analysis has enabled familiarisation with the principles of creating advertising slogans in yachting and their most prominent strengths and weaknesses. Hence professionals involved in designing and releasing advertising slogans may also find the results of the study useful.

\section{KEY WORDS}

$\sim$ Advertising

$\sim$ Slogan

$\sim$ Yachting

$\sim$ Linguistics

$\sim$ Analysis

\section{INTRODUCTION}

Advertising slogans are simple and memorable phrases that are designed to capture the essence of a product or a service and to efficiently relay the essential message a company (or country, city, destination...) wants its audience to remember. This paper discusses the language features and the function of slogans advertising sail and power yachts and boating equipment and services, hereafter referred to as "yachting slogans". The corpus consists of slogans that appeared on the pages of four nautical magazines, in their issues that came out over a one year period. ${ }^{1}$ Other "non-yachting" slogans, used for illustration and comparison with yachting slogans, have been borrowed from the works cited in the list of references. Like all advertising messages, yachting slogans are designed to attract attention of the target population, to create desire and drive to action. The objective of the paper has been to identify and analyse specific features of yachting slogans at phonological, lexical, syntactic and semantic levels, with due attention drawn to their functionality in comparison with the messages relayed by slogans in other trades. The descriptive method has been applied to define and explain the meaning and purpose of the slogans. The stylistic analysis has been used to identify the tools that make yachting slogans original, functional and able to deliver specific messages to a specific consumer niche. The study has revealed that these messages have their intrinsic discourse and a recognisable "personality" of their own. The study has also enabled familiarisation with the principles and techniques of creating advertising slogans. The presented analysis of features, specific potentials and constraints of these short phrases provides

1. More, 2010, Frabra press d.o.o., Croatia; Nautica, 2009, Profectus media d.o.o. (Croatian edition); Yachts Croatia, 2013, D. Š. Savjetovanje d.o.o.; Val navtika, 2013, Val navtika d.o.o., Slovenia. 
on how efficiently the slogan is tied to a jingle (e.g. Calgon) and other audio and video material. Yet, the crucial factor that makes a slogan memorable is its own "personality", i.e. the language features and the message it conveys.

\section{LINGUISTIC FEATURES OF SLOGANS IN YACHTING ADVERTISMENTS}

The language used in advertising slogans is essential to the message they want to convey. Given their delicate mission, many yachting slogans make use of rhetoric devices, figures of speech and other tools which can be examined and discussed at phonological, morphological, lexical, syntactic and semantic levels.

\subsection{Phonological Aspect}

Mnemonic devices that help advertising slogans to be remembered by their targeted audience include sound techniques such as alliteration, assonance, rhythm, and rhyme. The latter is a very frequent phenomenon in advertising, commonly used in jingles, slogans and headlines. English is particularly suitable for creating rhymes due to a large number of one-syllable words. While the rhyme is quite common in slogans advertising children products and mass-consumption products (Go well. Go Shell. - Shell; The best a man can get - Gillette; Do you ... Yahoo!? - Yahoo!), it is not very frequent in yachting advertisements, as they address a limited upscale clientele. Still, rhyme is not entirely banished: Innovation, performance \& Iuxury. Be the part of Sunseeker family. (Sunseeker charter); Safe. Strong. Fast. Built to last. (Tailored marine, Queensland); Sea Symphony (Elan 400).

The latter example provides the assonance - another sound [i] in the second syllable, and the alliteration (repetition of similar vowel sounds). This combination is a dominant sound technique that ensures a remarkable euphonic effect (in the following examples the assonance is underlined whereas the alliteration is marked in boldface type): The sunny side of life (Monachus power boats); Queen of the seas since 1968 (Ferretti Yachts); Motion and Mobility (ZF Transmissions); Set sail for success (Sealease service); A Riva is a Riva. Always. (Riva yachts - Ferretti Group). Assonance and alliteration can help the slogans to achieve a strong rhythm "needed to make it a repeatable sentence [...] easily remembered by the audience" (Thi and Thuy, 2010). It is a very effective device which contributes to remembering both the acoustic and visual forms of a slogan.

Admen pay particular attention to graphics - colour, type and size of the script. It is not possible here to engage in a detailed analysis of graphic features of yachting slogans, but it is only fair to draw attention to the most frequent technique - capitalisation. Barbora Machynková distinguishes two types.
The initial capitalization has an emphatic effect because the advertising message looks like a headline, like in Sea Ray's Where Land Ends, Life Begins. As a result, the meaning of each word is pointed out. It is typical for English language (Machynková, 2009). Full capitalisation is used in advertising slogans for similar reason: in Heesen Yachts' Passion, Performance, Perfection, words are written in small capital letters whereas the initials are normally capitalised, thus graphically reinforcing a strong alliteration of three P's and creating a beating effect - the rhythm.

Rhythm is often used in language of advertising as it has a powerful emotional and mnemonic effect that makes an advertisement or a slogan more memorable. The listener or reader may perceive it subconsciously without even noticing the effect. In literature, rhythm can be achieved by an extensive use of euphonic tools such as assonance, alliteration and rhyme as well as by the alteration of stressed and unstressed syllables. The repetition of similar or identical patterns of strong and weak stresses in lines of poetry is called metre. Yachting slogans almost always feature a regular metre (in the following examples the stressed syllables are marked in boldface type), such as an iamb, an unstressed syllable followed by a stressed syllable (Become unique - Velvet 115); a trochee, a stressed syllable followed by an unstressed one (Powering business worldwide - Eaton powerware); a spondee, consisting of two stressed syllables (Your turn! - Lagoon 52); a cretic, having an unstressed syllable between two stressed ones (Breaking rules. Setting trends Hanse yachts), etc.

\subsection{Lexical and Morphological Aspect}

Given the targeted population of well-to-do consumers who can afford to own or rent a boat, slogans that advertise boating brands have specific qualities at the lexical level. Unlike words that are commonly used to direct the consumer preference towards mass-consumption products (good, better, best, beautiful, real, great, pure, perfect...), the selection of nouns and adjectives used in yachting slogans reveals the values that are advertised as essential in boating (and living). According to a number of the above-quoted messages, being at sea means being alive again: Launch into living (Sea Ray), Start living (Boot-Düsseldorf boat show). Sailing awakens emotions, imagination and dreams (Your Ultimate Wave Dreams - Brioni 44; Dare to dream - Princess 58; Own the dream - Vicem yachts). Furthermore, being at sea means to be free and independent (The power to be independent - Mastervolt electric equipment). Boating implies the absence of everyday limits (No limits - Mira, Alena \& Fashion Yachts), it is associated with sophisticated life-style and elegance (Simplicity with style - Monachus power boats), and it ensures luxuries such as solitude and tranquillity (The value of the tranquillity -Lexsia yachts). Even the slogans that advertise pumps and marine toilets make use of the same word corpus, as in the lengthy and 
alliteration-loaded Powerful, efficient flush. Luxurious comfort (4800 Series VacuFlush Toilets - Dometic Sealand Group).

Excessive exploitation of certain motives (living, dream, style, emotion, performance, perfection...) may reduce the strength of the desired effect and, even worse, lead to confusion. It is not surprising that a designer unintentionally creates a slogan that already exists: for example PASSION, PERFORMANCE, PERFECTION is used by Dutch yacht builder Heesen Yachts while Passion, performance and perfection is used by Focus, German company that produces bicycles and cycling products. As it was pointed out, one of the crucial tasks of a slogan is to help differentiate the brand. In this particular case, both slogans failed, not only because they are identical, but also because in all sorts of trade there are a number of other slogans which use the same word corpus. The saturation of messages may lead to a glut of generic, hollow statements that "simply generate noise in today's marketplace" (Conley, 2010).

Yachting slogans seldom contain numerals. When they do, numerals usually evoke a tradition that guarantees the brand's quality: Yachts built on family bonds since 1875 (Lürssen), 125 years of heartfelt dedication (Dräger gas detecting equipment), Celebrating Adventure for 30 Years (Adriatic Croatia International Club).

Generally speaking, the choice of verbs is very careful in advertising. Although the ultimate purpose of advertising is selling and making profit, advertisements seldom use the word "buy". Instead, the most frequently used verbs and phrasal verbs include try, ask, get, take, let, send for, use, call, make, come on, hurry, see, give, come, remember, discover, serve, introduce, choose, and look for (Thi and Thuy, 2010). Yachting slogans largely follow the rules, avoiding any associations with buying or spending money. Instead, they make use of common alternatives such as take, get or discover, but also introduce specific verbs that are related to the above mentioned values: dare, capture, start, launch, sail, keep, feel, imagine, dream... The most frequent modal verb is "can": No storm can stop us (Aicon yachts), An idea can take you anywhere (Pershing power boats), Control Solutions You Can Trust (Dynagen Controller). These examples also contain possessive and personal pronouns (you, us...) that tend to shorten the distance between producers and consumers and are therefore used in advertising discourse more often than in other discourses. The most powerful ones are pronouns you and your because they suggest personal relationship: Our technology, your emotion (Sacs S680).

Other lexical features include building new words (Solutioneering Together - Yanmar), collocations (Breaking rules. Setting trends - Hanse; So worth it - Bayliner), and intertextuality, i.e. the way one text echoes or refers to another text, a phenomenon sometimes difficult to recognize. Intertextuality can be inter-generic, e.g. Evolution of the species (Azimut 54), referring to Charles Darwin's theory of evolution, or intra-generic, meaning that one slogan refers to another one. The above quoted Dometic Sealand Group's slogan echoes in a series of messages supporting similar products (parallelisms are underlined or marked in boldface type or upper case):

Powerful, efficient flush. Luxurious COMFORT.

Inspired by COMFORT.

Powerful performance. Premium COMFORT.

Compact Design. Powerful, efficient flush.

\subsection{Syntactic Level}

The syntax of the slogans promoting boats and boating equipment and services may include various sentence types, everyday phrases, ellipsis, parallelism, repetition, idioms and, to a certain extent, other rhetorical devices. In general, noun phrases in advertisements are far more frequent than verb phrases. ${ }^{5}$ Often, the advertising text does not contain any verb; it consists only of noun phrases, as in Support without limits (BluePoint Yachting) or The Heart of the Yacht (Volvo Penta). Adjectives are combined with nouns: Unbeatable for Quality and Performance (Gianneschi pumps and blowers) or used independently, usually in clusters, as in Reliable, Clean, Quiet - and Powerful (Cummins marine engines). If verbs are used, the phrase may be exclamative (Your imagination is the limit! - Vanga 44; What a yacht - Bavaria; Way of life! - Suzuki outboard engines), but most frequently imperative: Capture the dream (Azimut 58); Join the movement (Garmin GPSMAP 720s); Keep Sailing (Hempel). Along with imperative, the prevailing verb forms include the present simple tense, usually in the third person singular (feels / is / ends / begins...), and gerunds: Meeting regulations, protecting lives, lowering costs (McMurdo safety equipment). ${ }^{6}$

Parallelisms are seldom used, but when they are, they contribute to building the rhythm that has already been developed at the phonological or lexical level (Explore your world without leaving your home - Bandido 75; A small family business for big family fun! - Splendor power catamarans). Anaphora is a rhetorical device repeating the same word or group of words at the beginning of successive clauses or verses to emphasize an image or a concept, as in Feels like home. Feelin' alive (Bond Alena 48). It inevitably includes alliteration, in this particular case: [f-I // $\mathrm{f}-\mathrm{I}]$. Unlike advertisements of mass-consumption products, which abound with epiphoras (repeating the same lexical material at

5. More about sentence types and patterns in: Jana Lapšanská, (2006), The language of advertising with the focus on the linguistic means and the analysis of advertising slogans, Comenius University in Bratislava.

6. See also the above examples of slogans containing: solutioneering, celebrating, powering, breaking, setting.. 
the end of successive clauses or lines), the corpus of the observed yachting slogans does not include a single example. ${ }^{7}$

On the other hand, they teem with elliptical structures. Phrases often lack essential elements such as nouns (subjects, objects), verbs, conjunctions... In the tour-de-force slogans ISAKINDOFMAGIC and ISACHOICE, it is clear that something is missing but it is not clear whether it is a noun, i.e. the boat Isa 120 , or the verb IS and the indefinite article A - in case the capitals ISA are taken as the acronym of the Italian boatbuilder. According to Jana Lapšanská, the reader of the advertisement "turns to the visual layout, which provides him/her many clues to correct interpretation, so the explicit structure of the sentence is not so important" (Lapšanská, 2006). In Shuts down outboard thieves, it is not necessary to insist on the agent, as the name and image of the agent (Y-COP security system) appear in the photograph. The sunny side of life is an unpretentious phrase that sounds like a promise. As it is accompanied by an image of a Monachus power boat, it would be redundant and potentially counter-productive to avoid the ellipsis and say "Monachus power boats take you to the sunny side of life / enable you to experience the sunny side of life."

\subsection{Semantic Level (Figurative Language)}

Slogans that appear in boating magazines feature a variety of tropes, i.e. words or phrases that are "used in a way that is different from its usual meaning in order to create a particular mental image or effect" (Oxford Advanced Learner's Dictionary, 2001). Figurative language of yachting slogans includes metaphor, personification, metonymy, hyperbole, antithesis and, less frequently, pun (word play), symbol or paradox.

Dubovičienè and Skorupa point out that metaphor contributes to the aesthetics of the message and emphasizes the main idea, "describing one object in terms of another, usually by means of implicit comparison", listing a number of famous slogans: Bounty - the taste of paradise (Bounty candy bar), Put a tiger in your tank (Esso), It gives you wings (Red Bull) (Dubovičienè and Skorupa, 2014). Correspondingly, metaphor is an efficient tool in yachting advertisements. Here are some of the slogans that have already been discussed: Sea Symphony, Queen of the seas since 1968, The Heart of the Yacht.

Metonymy uses a single characteristic of a person, product, system or phenomenon to identify the entire entity. The

7. See epiphoras in these examples (marked in boldface type): If anyone can, Canon can (Canon), Buy it. Sell it. Love it (Ebay), Heavy industries. Happy industries (Hyundai), See new. Hear new. Feel new (Nokia). (T. Dubovičienè and P. Skorupa, (2014), The Analysis of some Stylistic Features of English Advertising Slogans, Man and the Word / Foreign Languages, Vol. 16, No. 3, pp. 61-75, Lithuanian University of Educational Sciences.

8. For example, the British monarchy is often referred to as the "Crown". association is always logical. ${ }^{8}$ In Simplicity with style, metonymy is used to underline one of the recognisable features (simplicity) of a complex and therefore complicated product such as a cruising power yacht, namely Monachus lobster. There is also a noticeable effect of antithesis (simplicity / complexity). Antithesis is a figure of speech which expresses two opposite ideas in order to emphasise the meaning and the contrast: $A$ small family business for big family fun! (Splendor power catamarans); Perfect Epoxy for an imperfect world (WEST System Epoxy). Hyperbole, a deliberate use of overstatement or exaggeration to achieve emphasis, is also frequent in yachting slogans: For Emperors and Princesses (Brioni 44); No storm can stop us (Aicon yachts); Making progress possible (Caterpillar marine engines). Other forms of figurative language in yachting slogans include personification, attribution of human qualities to inanimate objects (Yachts with Ambition - Steeler Yachts), and synaesthesia, blending of different sense modalities (Blue Power - Victron Energy electric products). These tropes represent a potential goldmine: they are not overexploited and are consequently "fresher" and more efficient.

The same goes for all the other underused language tools at the phonological, lexical, syntactic and semantic levels, i.e. transliteration (transformation of foreign words into English), pun (word play), symbol, paradox, polysemy, etc. It might be a sound business decision to make more use of them, instead of insisting on the overexploited language resources that have become hollow and inefficient.

\section{CONCLUSION}

Unlike every-day marketing discourse or any other discourse associated with boating (specification, reviews, tests of vessels and equipment, articles... ), yachting slogans abound in linguistic techniques and figures of speech which have been discussed here at phonological, lexical, syntactic and semantic levels. It has been found out that, although yachting slogans comply with the general advertising rules, tending to be simple, euphonic, mnemonic, etc., they often adopt a distinct "personality" of their own.

At the phonological level, specific mnemonic devices have been observed. While rhymes - often associated with mass production - are rather rare, yachting slogans abound in alliteration, assonance and other tools that create euphony and rhythm. The latter is further reinforced by using regular metres, i.e. alteration of similar or identical patterns of strong and weak stresses.

Given the targeted market niche, yachting slogans have certain specific qualities at the lexical level as well. The dominant word forms are not adjectives but nouns - usually referring to a limited group of motives associated with living, 
style, elegance, emotions, imagination, dreams, independence, exploration, solitude, harmony, perfection. Slogans often refer to a boatbuilding tradition as a guarantee of quality. The corpus of the observed slogans has revealed an excessive exploitation of certain motives (living, dream, style, perfection...). Such slogans fail to carry out their principal task - to differentiate the brand. Overused words become trite, vacuous phrases to an average consumer. This may result in undesired effects and should be evaded in advertisement designing. Like slogans in other trades, yachting slogans avoid associations with buying or spending money by using verbs like take, get or discover, but they also use specific verbs such as dare, capture, launch, sail, imagine, often in the form of imperatives or gerunds. Pronouns like you, we, us, our, your... are essential in suggesting personal relationship between producers and consumers.

The syntax of yachting slogans does not include all sentence types. Elliptical structures and noun phrases, with or without adjectives, are dominant. Yachting slogans never use questions, rhetorical questions that assume one possible answer, presuppositions, or comparisons. Parallelisms like anaphoras are sometimes used to reinforce the rhythm that has already been developed at the phonological or lexical level.

Finally, at the semantic level, slogans that appear in boating magazines frequently use figurative language, especially metaphor, metonymy, hyperbole and antithesis. Unlike advertising messages in other trades, yachting slogans seldom use synaesthesia, personification, pun, symbol, polysemy, or paradox. The low frequency of these tropes is potentially a great opportunity: from the business standpoint, it might be sound to use them more frequently, instead of insisting on the overexploited language resources that do not appeal to the targeted consumers efficiently any more.

Table 1.

List of the Advertising Slogans in Yachting Examined in this Paper (in Order of Appearance).

\begin{tabular}{|c|c|}
\hline Imagination at Work & (General Electric) \\
\hline Launch into living & (Sea Ray) \\
\hline Different... Like you & (Saltus brokerage \& charter) \\
\hline Get everything. Power, space and style. Live Itama. & (Itama yachts) \\
\hline Diversity is beautiful & (Kvarner region) \\
\hline Innovation, performance \& luxury. Be the part of Sunseeker family. & (Sunseeker charter) \\
\hline Safe. Strong. Fast. Built to last. & (Tailored marine, Queensland) \\
\hline Sea Symphony & (Elan 400) \\
\hline The sunny side of life & (Monachus power boats) \\
\hline Queen of the seas since 1968 & (Ferretti Yachts) \\
\hline Motion and Mobility & (ZF Transmissions) \\
\hline Set sail for success & (Sealease service) \\
\hline A Riva is a Riva. Always. & (Riva yachts - Ferretti Group) \\
\hline Where Land Ends, Life Begins. & (Sea Ray) \\
\hline Passion, Performance, Perfection & (Heesen Yachts) \\
\hline Become unique & (Velvet 115) \\
\hline Powering business worldwide & (Eaton powerware) \\
\hline Your turn! & (Lagoon 52) \\
\hline Breaking rules. Setting trends. & (Hanse yachts) \\
\hline Start living & (Boot-Düsseldorf boat show) \\
\hline Your Ultimate Wave Dreams & (Brioni 44) \\
\hline Dare to dream & (Princess 58) \\
\hline
\end{tabular}




\section{Own the dream}

The power to be independent

No limits

Simplicity with style

The value of the tranquillity

Powerful, efficient flush. Luxurious comfort

Yachts built on family bonds since 1875

125 years of heartfelt dedication

Celebrating Adventure for 30 Years

No storm can stop us

An idea can take you anywhere

Control Solutions You Can Trust

Our technology, your emotion

Solutioneering Together

So worth it

Evolution of the species

Inspired by comfort.

Powerful performance. Premium comfort.

Compact Design. Powerful, efficient flush.

Support without limits

The Heart of the Yacht

Unbeatable for Quality and Performance

Reliable, Clean, Quiet - and Powerful

Your imagination is the limit!

What a yacht

Way of life!

Capture the dream

Join the movement

Keep Sailing

Meeting regulations, protecting lives, lowering costs

Explore your world without leaving your home

A small family business for big family fun!

Feels like home. Feelin' alive

ISAKINDOFMAGIC

ISACHOICE

Shuts down outboard thieves

Perfect Epoxy for an imperfect world

For Emperors and Princesses

Making progress possible

Yachts with Ambition

Blue Power
(Vicem yachts)

(Mastervolt electric equipment)

(Mira, Alena \& Fashion Yachts)

(Monachus power boats)

(Lexsia yachts)

(VacuFlush Toilets - Dometic Sealand Group)

(Lürssen)

(Dräger gas detecting equipment)

(Adriatic Croatia International Club)

(Aicon yachts)

(Pershing power boats)

(Dynagen Controller)

(Sacs S680)

(Yanmar)

(Bayliner)

(Azimut 54)

(Dometic Sealand Group)

(Dometic Sealand Group)

(Dometic Sealand Group)

(BluePoint Yachting)

(Volvo Penta)

(Gianneschi pumps and blowers)

(Cummins marine engines)

(Vanga 44)

(Bavaria)

(Suzuki outboard engines)

(Azimut 58)

(Garmin GPSMAP 720s)

(Hempel)

(McMurdo safety equipment)

(Bandido 75)

(Splendor power catamarans)

(Bond Alena 48)

(ISA Yachts)

(ISA Yachts)

(Y-COP security system)

(WEST System Epoxy)

(Brioni 44)

(Caterpillar marine engines)

(Steeler Yachts)

(Victron Energy electric products) 


\section{REFERENCES}

Conley, S. J., (2010), Sloganology: The Anatomy of Slogans, Miami, FL: The Slogan Shop, available at: http://www.thesloganshop.com, [accessed 02 September 2015.].

Dubovičienè, T. and Skorupa, P., (2014), The Analysis of Some Stylistic Features of English Advertising Slogans, Man and theWord/Foreign Languages, 16(3), pp. 61-75., http:/dx.doi.org/10.15823/zz.2014.013

Foster, T. R. V., (2001), The Art \& Science of the Advertising Slogan, ADSlogans Unlimited, available at: http://www.adslogans.co.uk, [accessed 02 September 2015.].

Ke, Q. and Wang, W., (2013), The Adjective Frequency in Advertising English Slogans, Theory and Practice in Language Studies, Academy Publication, 3(2), pp. 275-284., http://dx.doi.org/10.4304/tpls.3.2.275-284

Lapšanská, J., (2006), The Language of Advertising with the Focus on the Linguistic Means and the Analysis of Advertising Slogans, Diploma thesis, Bratislava: Comenius University in Bratislava, Faculty of Education.

Machynková, B., (2009), Translation in Advertising - Transfer vs Adaptation, BSc thesis, Zlin: Tomas Bata University, Faculty of Humanites.
Nautica (Croatian edition), January-December 2009, Profectus media d.o.o., Split, Croatia.

O'Guinn, T. C., Allen, C. T. and Semenik, R. J., (2012), Advertising and Integrated Brand Promotion, $6^{\text {th }}$ ed., Mason, $\mathrm{OH}$ : South-Western, Cengage Learning.

Slogan at Wikipedia, available at: https://en.wikipedia.org/wiki/Slogan, [accessed 02 September 2015.].

Solomon, E. home page (Ediwriter Professional Copywriting Co.), New York City, USA, available at: http://www.ediwriter.com, [accessed 02 September 2015.].

Thi, B. and Thuy, B., (2010), An Investigation Into the Style of the English Language Used in Advertising Slogans Issued by Some World-Famous Airlines, available at: http://text.123doc.org/document/78840-an-investigation-into-the-style-of-theenglish-language-used-in-advertising-slogans-issued-by-some-world-famousairlines.htm, [accessed 02 September 2015.].

Val navtika magazine, January-December 2013, Val navtika d.o.o., Ljubljana, Slovenia, available at: http://www.val-navtika.net, [accessed 02 September 2015.].

Yachts Croatia, January-December 2013, No. 25-30, D. Š. Savjetovanje d.o.o., Split, Croatia, available at: http://issuu.com/yachtscroatia, [accessed 02 September 2015.].

More magazine, January-December 2010, Fabra press d.o.o., Croatia. 